\title{
Adapting pastoral breeding to global changes in West and Central tropical Africa: Review of ecological views
}

\author{
Pierre Hiernaux $^{1 *}$ Mohamed Habibou Assouma ${ }^{2,3}$
}

\section{Keywords}

Pastoralism, adaptation, climate change, social change, ecology, Africa South of Sahara

Submitted: 2 October 2018

Accepted: 11 December 2019

Published: 23 September 2020

DOI: $10.19182 /$ remvt.31893

\begin{abstract}
Summary
Pastoral livestock is defined as a reproduction-oriented, grazing-based familial livestock system with community-managed resources. Pastoral breeders differ from one another in the diversity of species and breeds raised, the size and management of herds and the extent of their regional mobility. The social, economic and environmental weight of pastoralist livestock in West and Central sub-Saharan Africa is evoked together with its imputation of environmental degradation. Global changes faced by pastoral livestock are sorted out by domains, climatic and societal, and by time scales, short or long. The incriminated impacts of livestock on ecosystems are assessed in the short and long terms. The functions of pastoral breeding already affected by global changes whether climatic or societal are analyzed. The capacity of two alternative livestock breeding systems, ranching and stall-feeding, to respond to these constraints is reviewed. Finally, pastoral breeding has been recognized as being able to adapt best to long-term climate change and to short- and long-term societal changes, provided that national and international investments are made. Civil security must be restored and pastoralists' access to water and fodder resources must be secured. Professional organizations and associations should be empowered to negotiate grazing rights, and their skills should be enhanced. There is the need to complete, rehabilitate and manage hydraulic and veterinary infrastructures, but also to invest significantly in adapted health, education and communication infrastructures in long-neglected pastoral areas.
\end{abstract}

- How to quote this article: Hiernaux P., Assouma M.H., 2020. Adapting pastoral breeding to global changes in West and Central tropical Africa: Review of ecological views. Rev. Elev. Med. Vet. Pays Trop., 73 (3): 149-159, doi: 10.19182/remvt.31893

\section{INTRODUCTION}

Pastoral breeding in West and Central sub-Saharan Africa, from the southern fringes of the Sahara to the northern fringes of the tropical forest, carries a mixed image. On one hand, the iconic longhorn zebu herds walk proudly in Sahel immensity, image of harshness and resilience. On the other hand, the dramatic spectacle of carcasses drying along livestock paths and the desperation of impoverished pastoral families trying to survive in urban suburbs offer images of failure and vulnerability. These contrasted images fuel a narrative on the adaptation crisis of a production system, a way of life and a culture,

\footnotetext{
1. Pastoralisme Conseil, 30 chemin de Jouanal, 82160 Caylus, France.

2. CIRAD, UMR SELMET, F-34398 Montpellier, France.

3. SELMET, Univ Montpellier, CIHEAM-IAMM, CIRAD, INRAE, Institut Agro, Montpellier, France.

* Corresponding author

Email: pierre.hiernaux2@orange.fr
}

all perceived as traditional (Gallais, 1975; Bonfiglioli, 1988; Ag Mahmoud, 1992), thrown into a world of changes: large societal changes and deep environmental changes. To the long-standing criticisms of disorganized activities that are the source of conflicts (Thebaud and Batterbrury, 2001), and poor productivity (Doutressoulle, 1952; Krätli, 2005), pastoral breeding is also accused of contributing to ecosystem degradation, locally through overgrazing (Sinclair and Fryxell, 1985) or globally through its part in greenhouse gas emission, particularly enteric methane by ruminants (Gerber et al., 2013). Yet livestock production leads the agriculture economy of many states in the region by contributing $20-40 \%$ of the agricultural gross domestic product of the Sahelian states (de Haan et al., 2016). Pastoral livestock constitutes the main asset of millions of pastoral and agropastoral families (Kruska et al., 2003). It is essential to soil fertility maintenance (Bationo and Mokwunye, 1991). Moreover, the market demand for livestock products is rapidly increasing (Zoundi and Hitimana, 2008; de Haan et al., 2016) with the overwhelming urbanization in the whole region (Denis and Moriconi-Ebrard, 2009), the share of the sub-Saharan urban population reaching $40 \%$ in 2015 from 10\% in 1950 (United Nations, 2018). 
Pastoral breeding is very diverse as a result of a long history of adaptation to diverse biophysical environments, and to particular social and political contexts in West and Central sub-Saharan Africa (Le Houérou, 1989; Raynaut, 2001). Livestock species include various local breeds of zebu and taurine cattle, hair and wool sheep, tall and dwarf goats, pack and dairy camels, horses and donkeys, diversely associated in each pastoral familial group (Ickowicz et al., 2012). Breeding also differs by the size of the herds, from a few head to several hundred, and by the seasonal herd mobility associated or not to family mobility. In addition, breeding is frequently associated with other economic activities within pastoral families including crop farming (agropastoralism), trade (e.g. caravans), craft, therapy and religion (Manoli et al., 2014). In pastoral breeding, animals are mostly fed by direct grazing and browsing (Lhoste et al., 1993). Cut and carry, hay and haulms, grains or agro-industrial feeds remain exceptional and are used to feed supplements to selected animals during limited periods. Privileging grazing and browsing to feed livestock establishes a strong dependence of the animal condition and production on the fodder availability and quality. Optimizing grazing selection is thus driving herd management: timing for grazing, drinking, resting along the daily grazing circuit, seasonal transhumance, and access-right negotiations (ZDF, 2008; Krätli and Schareika, 2010; Ayantunde et al., 2018).

A second trait shared by all pastoral breeding is that animal reproduction is the main objective, implying the dominance of reproductive females in the herd composition as in the example of pastoralist compared to agropastoralist herds in Western Niger (Figure 1), whereas young males prevail in sales (Wilson, 1986). The large share of reproductive females brings an opportunity for milk production. However, the breeds adapted to harsh conditions and poor seasonal forage resources have limited milk production (Sanogo, 2011). Only a fraction of that production is milked to satisfy the nutritional needs of pastoral families whereas seasonal surpluses are sold on local markets. However, feeding calves, kids, lambs or young camels is always privileged (Hiernaux et al., 2016a). The reproductive vocation of pastoral breeding provides the link with specialized and sedentary livestock production systems such as feedlots, fattening units, dairy farms, and animal draft units, by supplying these systems with young animals mostly via livestock markets (Wane et al., 2009). Yet, in the context of an ever-growing population, along with the expansion of cropped areas and landscape fragmentation, pastoral and specialized husbandry increasingly compete for grazing resources (Turner et al., 2014).

Adapting further the diverse forms of pastoral breeding to global changes requires: i) to sort out and prioritize the components of changes relative to climate, water, vegetation, soil and society; ii) to evaluate the impact of grazing livestock on the ecosystems of West and Central tropical Africa; iii) to analyze the functions of pastoral breeding already affected by global changes, either climate or societal; and iv) to review the capacity of alternative livestock breeding systems to respond to these constraints. To conclude, the pathways for adapting pastoral breeding to global changes are discussed.

\section{GLOBAL CHANGES}

Global changes result from intricate and nested changes in climate and related soil and hydrology, and in society (Brooks et al., 2005).

\section{Long-term climate change}

Global changes first evoke climate change whose mention has become compulsory in any research or development project conducted in West and Central sub-Saharan Africa, including pastoral breeding (World Bank, 2015). As everywhere else on the globe, climate is affected by increasing air temperatures in relation with higher concentrations of greenhouse gases, especially $\mathrm{CO}_{2}, \mathrm{CH}_{4}$ and $\mathrm{N}_{2} \mathrm{O}$ (IPCC, 2013). The mean annual temperature has increased by $1-2^{\circ} \mathrm{C}$ between 1950 and 2010. However, in the context of the West African monsoon that prevails in the region, the increase in temperature mostly affects the warmest months at the end of the dry season and shortly at its onset, and mostly by higher daily minimum temperatures (Guichard et al., 2017). It thus has little impact on most plants including crop products of the wet season. According to the projections of the global models used by the Intergovernmental Panel on Climate Change (IPCC, 2013), temperatures should keep increasing in the 21st century by $1.7^{\circ} \mathrm{C}$ under the optimistic scenario (Representative Concentration Pathway $4.5 \mathrm{Wm}^{2}$ ) and by up to $4.3^{\circ} \mathrm{C}$ under the pessimistic scenario $\left(\mathrm{RCP} 8.5 \mathrm{Wm}^{2}\right)$.
Cattle pastoral

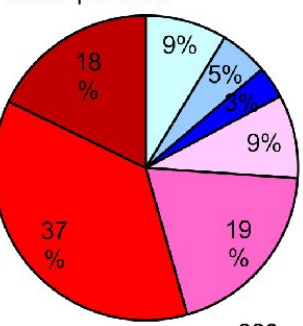

880

Cattle agropastoral

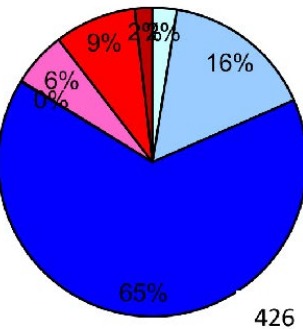

426

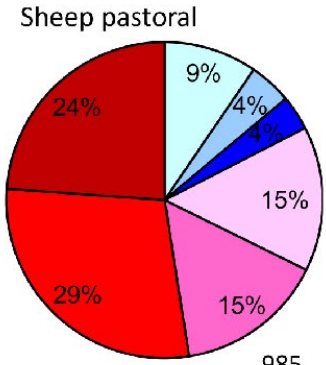

985

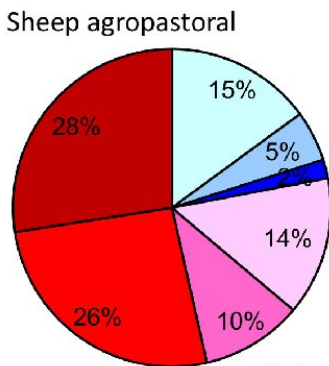

380

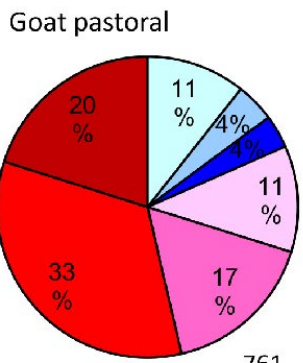

761

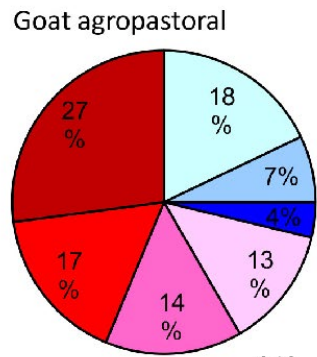

240

$\square \precsim$ unweaned $\square \delta$ young

$\square$ adult $\square$ qunweaned

$\square$ fyoung

$\square$ qadult

qlactating

Figure 1: Relative distribution of cattle, sheep and goats by sex and age class in 63 pastoral and 115 agropastoral farms in the district of Dantiandou, Southwestern Niger. Bottom right of pie charts: total number of animals (source: Hiernaux et al., 2015). 
The trend observed so far in rainfall distribution and the predictions based on global modeling contradict the popular and mediatic belief in an aridification (Lebel and Ali, 2009). After twenty-five years of poor rainfall starting in the late 1960 s, with two major droughts in 1973-74 and 1984-85, annual rainfall has increased in Central Sahel since the mid-1990s, and since early 2000 in Western Sahel (Nicholson, 2013). Yet, this return to a higher mean rainfall is spatially uneven with large interannual variations and it has not reached the levels of the wet 1950-1967 period. In addition, the pattern of rainfall is changing with no more rainy days than during the dry period 1968-1993 (Ozer et al., 2017) but with a higher frequency of heavy rains increasing the risk of floods (Panthou et al., 2014 ). This trend is sometimes accompanied by a higher frequency of dry spells within the wet season, increasing the risk of failure in crop and rangeland growth (Bichet and Diedhiou, 2018). If these trends are confirmed and continue, together with high temperatures and $\mathrm{CO}_{2}$ concentration in the atmosphere, $\mathrm{C} 3$ perennials including woody plants could tend to replace $\mathrm{C} 4$ herbaceous species leading to bush encroachment (Ghannoum et al., 2000; Poorter and Navas, 2003). Higher frequency of heavy rainfall events together with the reduction in the vegetation cover as a result of expanding cropped areas, roads and building infrastructures, and increased grazing pressure, will also promote runoff, ending in drastic changes in local water balances with higher shares of rainwater channeled to drainage lines, ponds and recharging aquifers (Favreau, 2002; Gardelle et al., 2010; Gal et al., 2017). Even the flood regime of the largest rivers have already been affected as in the case of Niger River in Niamey which developed an early flood peak fed by swollen local runoffs (Descroix et al., 2012).

\section{Societal changes driven by demography}

Storms, floods and droughts are spectacular events, but climate change is taking place over a longer period than concomitant societal changes that occur much faster and may have a larger impact in the short term. A major component of societal changes in West and Central sub-Saharan Africa is the rapid and lasting increase in population density at a rate of 3-4\% annually since mid-20th century (Guengant and May, 2011). It first affected the rural population that used to prevail, then it accelerated urban population growth in coastal countries and more recently in inland countries (Denis and Moriconi-Ebrard, 2009). Among the consequences that affect pastoral breeding, cropped areas are expanding at a rate close to that of human demography, i.e. about $3 \%$ a year, and with little intensification of these cropping systems (Breman et al., 2001; Powell et al., 2004). Crop areas increased at the detriment of rangelands and fallows as in the example of the district of Dantiandou in Western Niger (Figure 2). This process resulted in the fragmentation of grazing lands, which access required more care, closer herding and more beforehand negotiation by pastoralists. In addition, rangelands converted into croplands were generally the most fertile, leaving the less productive lands to grazing (Schlecht et al., 2006). The expansion of cropped areas is often accompanied by changes in tenure in favor of more private use of croplands, restricting communal use, including grazing rights (Turner et al., 2016). In some countries such as Senegal, Burkina Faso and Nigeria, land grabbing by agro-industries adds to the privatization of croplands. Reduction in rangeland resources, area and access are all obstacles to the regional and season transhumance of pastoral herds. Especially in the late dry season, transhumance toward subhumid and wetland areas is essential to Sahel pastoral breeding to keep livestock nutrition at an acceptable level, while grazing resources are getting very poor in the Sahel belt (Hiernaux et al., 2015).

On one hand, the gap in dry season resources is all the more severe because the livestock population also increases with the human population, although at a lower rate than in cropped areas (Corniaux et al., 2012). On the other hand, the civil insecurity that affects the Sahel as well as the north of costal countries raises additional obstacles to

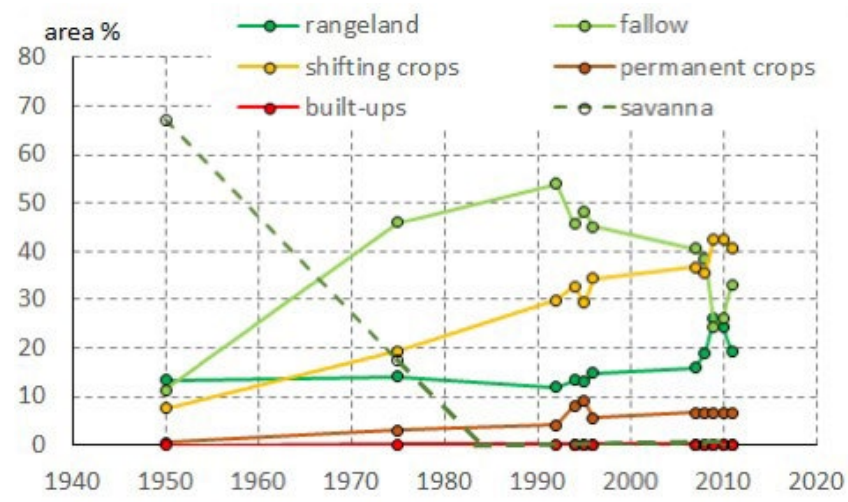

Figure 2: Example of change in land use over a 500- $\mathrm{km}^{2}$ area in Dantiandou District in Western Niger. Areas are estimated from a classification of aerial photos (1950-1996) and supervised classifications of SPOT imagery (2007 onward). The savanna was cleared for cropping and became extinct in the mid 1980s. The cropland is categorized as either shifting crop fields or permanently cropped and manured fields (source: Hiernaux et al., 2018).

livestock mobility in the wet and dry seasons (Déclaration de Ndjaména, 2013). Moreover, policies toward land privatization with titling of land plots to individual farmers and the settlement of mobile populations conducted in some of the costal countries have impaired further livestock mobility (Bassett, 1988; Maman Moutari and Giraut, 2013). A first adaptation by pastoral breeding families to the restricted access to vital pastoral resources was to diversify their economic activities, often through staple cropping to meet basic nutritional needs, which implied settling down part of the year and/or part of the family. Yet the enhanced economic activity agenda within pastoral families has also contributed to reduce the pastoral breeding skills of the young men in charge of herding and day-to-day livestock management, leading to shortages in skilled labor (Turner and Hiernaux, 2008). The increasing trend of crop farmers investing in livestock husbandry with a few head of small ruminants or cattle in addition to pack and draft animals does not compensate for the loss of skilled pastoral labor. The skilled labor shortage and civil insecurity in part result from a long history of public under investments in pastoral regions, starting in colonial time and pursued by the independent states. Except for recent electronic-communication services, pastoral areas are still poorly endowed with roads, health and education infrastructures in spite of their notable contribution to the domestic product.

CONCERNS ABOUT RANGELAND DEGRADATION BY OVERGRAZING

There is a persistent concern among technical services and research institutions, relayed by the media and political circles, about the detrimental impact of 'uncontrolled' grazing by pastoral livestock on vegetation and soils (Sinclair and Fryxell, 1985; Dodd, 1994; Steinfeld et al., 2006). The ecosystem degradation due to pastoral breeding fits well in the largely shared and long-lasting paradigm of desertification (Aubréville, 1949; Boudet, 1972; Brabant, 2010). In addition, as previously mentioned, grazing ruminants have been recently accused of significantly contributing to greenhouse gas emission.

\section{Short-term impact of livestock grazing}

In Sahel, rangelands and fallows are dominated by annual herbaceous species with scattered woody plants (Hiernaux and Le Houérou, 2006). Herbage growth is controlled by rainfall distribution with large spatial heterogeneity related to patchy rain distribution and to rain redistribution 
by runoffs (Mougin et al., 1995). This rainfall control also explains large interannual variations in yields (Figure 3a). Yet the productivity is strongly limited by the soil fertility, more specifically the poor content in both nitrogen and phosphorus as soils are generally sandy, acidic and poor in organic matter (Penning de Vries and Djiteye, 1982). The short-term impact of grazing on the annual herbaceous growth is limited to the wet season, especially when grazing occurs during the rapid growth at grass heading. However, this rapid growth only lasts two to three weeks about synchronal across Sahel (Figure 3a; Hiernaux et al. 2013). At worst, the herbaceous production repeatedly grazed is reduced by half (Hiernaux and Turner, 1996), but this mainly occurs very locally when livestock is concentrated during the wet season.

During the dry season, the annual herbaceous plants are dead so there is no impact on production (Figure 3b). The livestock at most ingests a third of the mass of standing straws at the onset of the dry season because of concomitant grass trampling, herbivorous insects and rodents, and organic decomposition (Hiernaux et al., 2015). It also entails that at least two thirds of the herbaceous mass standing at the onset of the dry season are recycled locally. In addition, about half of the forage intake by grazing livestock returns to soil as feces, as the mean digestibility of the selected diet by grazing livestock during the dry season is about 50\% (Ayantunde et al., 1999; Assouma et al., 2018). Livestock trampling changes standing straws into litter, then into buried litter pieces, dung and diaspores in the top soil. Trampling may enhance the subsoil density of fine-textured soils but has no impact on the subsoil density of the dominant sandy soils (Hiernaux et al., 1999). On the opposite, trampling enhances water infiltration and reduces soil erosion by cracking the top soil crust (Casenave et Valentin, 1992) while increasing surface roughness.

In subhumid and humid savannas in the south as well as in wetlands, herbaceous species are dominated by highly productive perennials, mostly tussock grasses. Similarly to annuals, these perennials are very sensitive to grazing during the rapid growth or grass heading (Cissé and Breman, 1975). However, the rapid lignification of the stem soon deters grazing (Fournier, 1996). After flowering and fruiting, the fodder value of the straws is very poor but the regrowth of perennials has good value in the dry season regardless of bushfires often lit to get rid of the mass of straw and litter, easing the access of livestock to the regrowth (César, 1981). Perennial grasses stand very well both regular fires and grazing of the dry season regrowth (Figure 4).
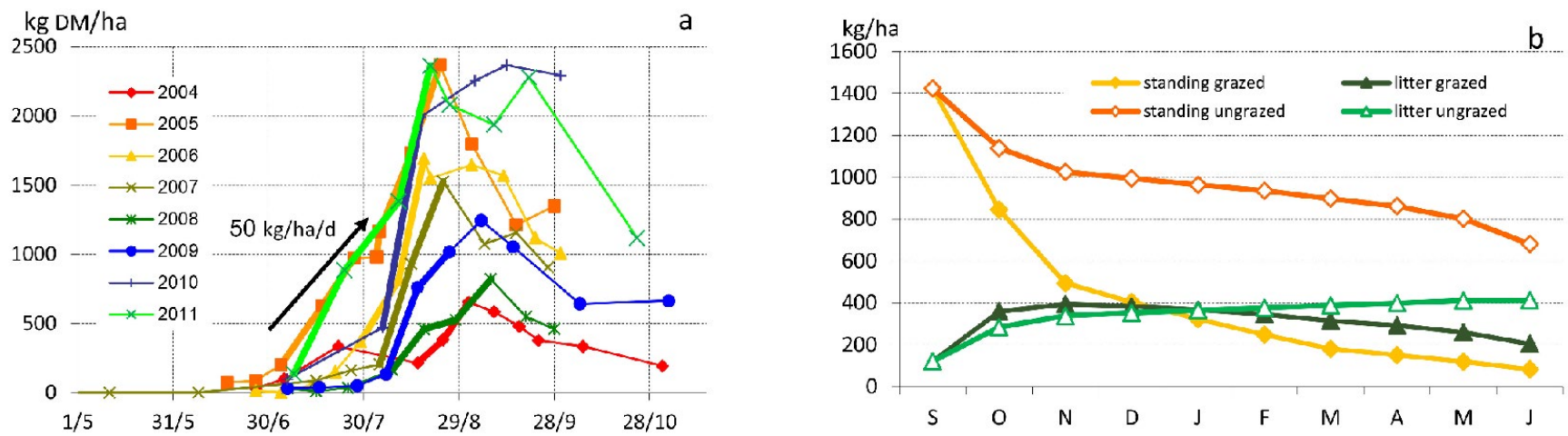

Figure 3: a) Herbage growth (x axis: day/month) in a rangeland site at Agoufou (Mali) from 2004 to 2011 showing the amplitude of interannual yield variations and the short duration of the rapid growth phase. b) Dry season decay of the mass of the standing straws and litter depending on grazing (source: Hiernaux et al., 2015). DM: dry matter
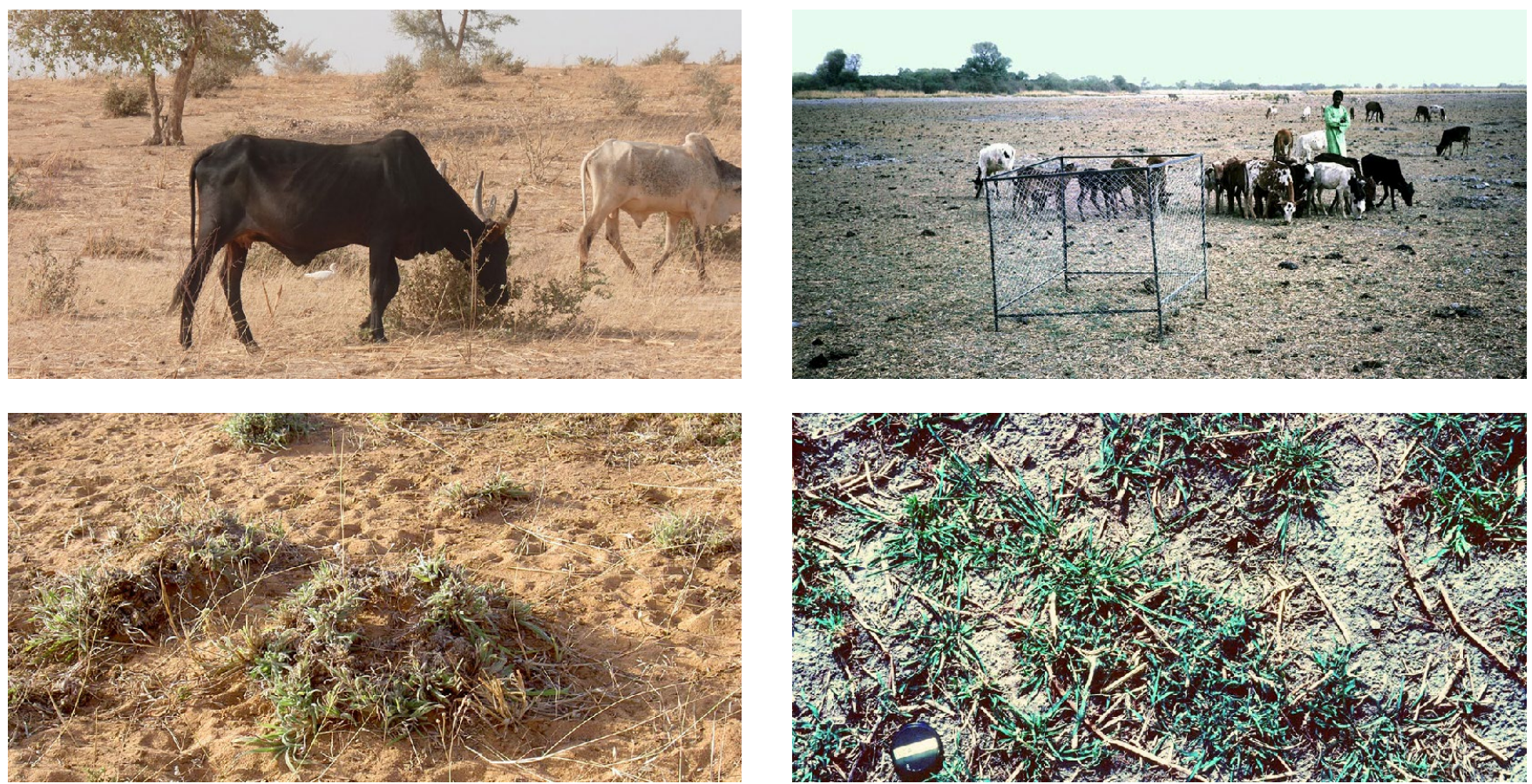

Figure 4: Grazing of perennial grass regrowth in the dry season. Left pictures: Andropogon gayanus in Dantiandou (Niger). Right pictures: Echinochloa stagnina at Moura (source: Inland Niger River Delta, Mali). 
Their maximum production is achieved at the specific defoliation frequency of every 15 days for Echinochloa stagnina (Hiernaux, 1984; Léauthaud et al., 2018). The recycling of nutrients in dedicated organs (rhizomes, tillering plateau) to meet plant needs at the next growing season is the main causal process of their resilience (Abbadie, 1984).

In spite of the notable contribution of the leaves and pods of selected woody plant species to the nutrition of livestock (Guerin, 1994), especially browsing goats and camels, the rate of leaf and twig harvesting relative to the total mass of leaves and twigs produced annually reaches at most a few percent (Assouma et al., 2017a). Even woody plants subjected to intense browsing, as they grow in livestock concentration sites, survive thanks to the reactive dense and short branching, bonsai-like, that impedes further leaf browsing (Figure 5a). Instead, the short-term impact of livestock browsing on woody plants may be caused by the pastoral practice of lopping branches to feed livestock. Cut branches may only be branchlets, which requires for the herder to climb on the tree. Larger branches may be partially cut and bent toward the soil to ease access to animals, practice known as the 'umbrella cut'. However, even with severe cuts and heavy browsing many trees survive as is the case of an Acacia raddiana tree in a pastoral site in Gourma, Northern Mali, monitored since 1984 and still thriving in 2007 (Figure 5b).

\section{Impact of livestock grazing on the longer term}

On the longer term, the grazing impact on the Sahelian herbaceous layer results from the combination of short-term effects of wet season foraging on the production and seed dispersion, of trampling that accelerates organic matter decomposition and enhances water infiltration, and of feces and urine deposit, all repeated over years. Altogether, comparing the herbaceous growth of 25 rangeland sites in Gourma monitored from 1984 to 2011 indicated that mean daily growth rates between grass tillering and heading in sandy-soil rangelands increased with the intensity of grazing pressure from 30 to $45 \mathrm{~kg} \mathrm{ha}^{-1} \mathrm{~d}^{-1}$ (Hiernaux et al., 2016). Long-term survey of rangelands in sandy soils in Senegal submitted to uncontrolled heavy grazing,

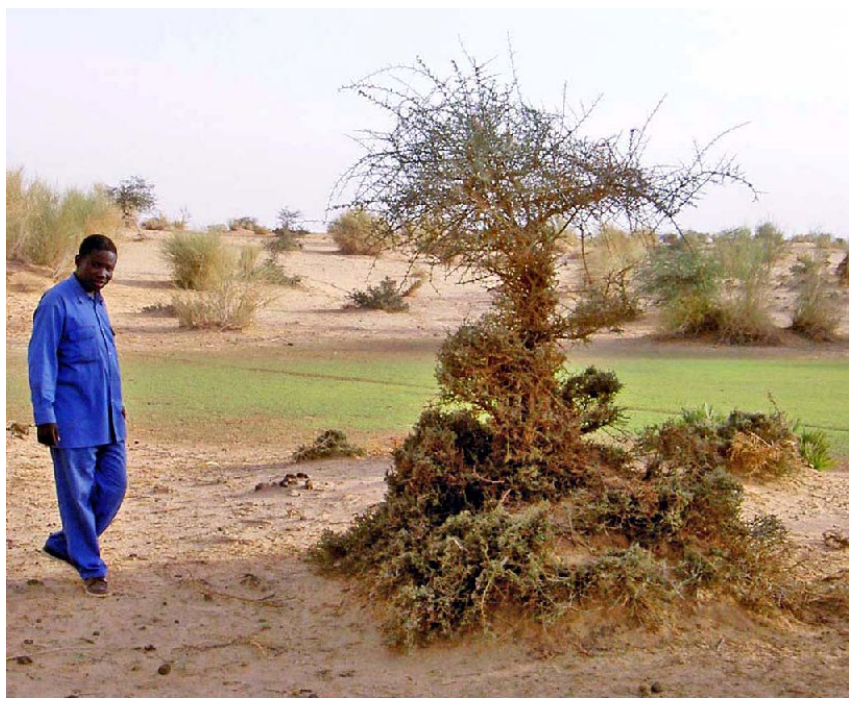

Figure 5: Top left: Balanites aegyptiaca bonsai shaped by browsing near Gourma-Rharous (Mali). Right: same Acacia raddiana in the foreground in 1984 (top) and in 2007 (bottom). controlled moderate grazing, and protection from grazing, indicates higher yields in controlled grazing and higher species diversity in protected rangelands, but more stable growth rates under heavy grazing (Miehe et al., 2010). Moderate grazing tends to promote C4 grasses, whereas high grazing pressure either favors highly productive poorly palatable dicotyledons such as Sida cordifolia or Cassia obtusifolia, or less-productive short-cycle palatable species such as Zornia glochidiata and Tribulus terrestris (Valenza, 1984; Hiernaux and Le Houérou, 2006).

Remote sensing assessments of vegetation growth based on the normalized difference vegetation index (NDVI) confirm the regreening (i.e. increased production) of Sahel rangelands after the early 1980s' drought (Anyamba and Tucker, 2005; Dardel et al., 2014; Brandt et al., 2014). Remote sensing works also confirm higher NDVI values, and thus vegetation production, at the vicinity of water ponds and pastoral camps in relation with higher soil fertility due to livestock manure deposit adding organic matter, nitrogen and phosphorus among other minerals (Hanan et al., 1991; Brandt et al., 2018; Rasmussen et al., 2018).

In subhumid and humid savannas, moderate grazing on the long term tends to favor tussock perennial grasses, whereas heavy grazing promotes refusal of dicotyledons and woody plants, with a risk of bush encroachment unless the savanna is regularly burned (César et Zoumana, 1993). In flooded grasslands such as the iconic burgu (in Fulani generic word of Echinochloa stagnina here used for this type of wetland), the intense grazing pressure at the retreat of the flood stimulates regrowth during the dry season and helps maintain the grassland on the long term by forcing plant reproduction (Hiernaux, 1984). Yet, increasing irregularity in the flood regime in relation with climate change, upstream damming and water withdrawal put a stress on wetland vegetation, often promoting bush encroachment as was the case with the introduced Prosopis juliflora that invaded the northern half of Lake Chad during the 1970-1980s' droughts.
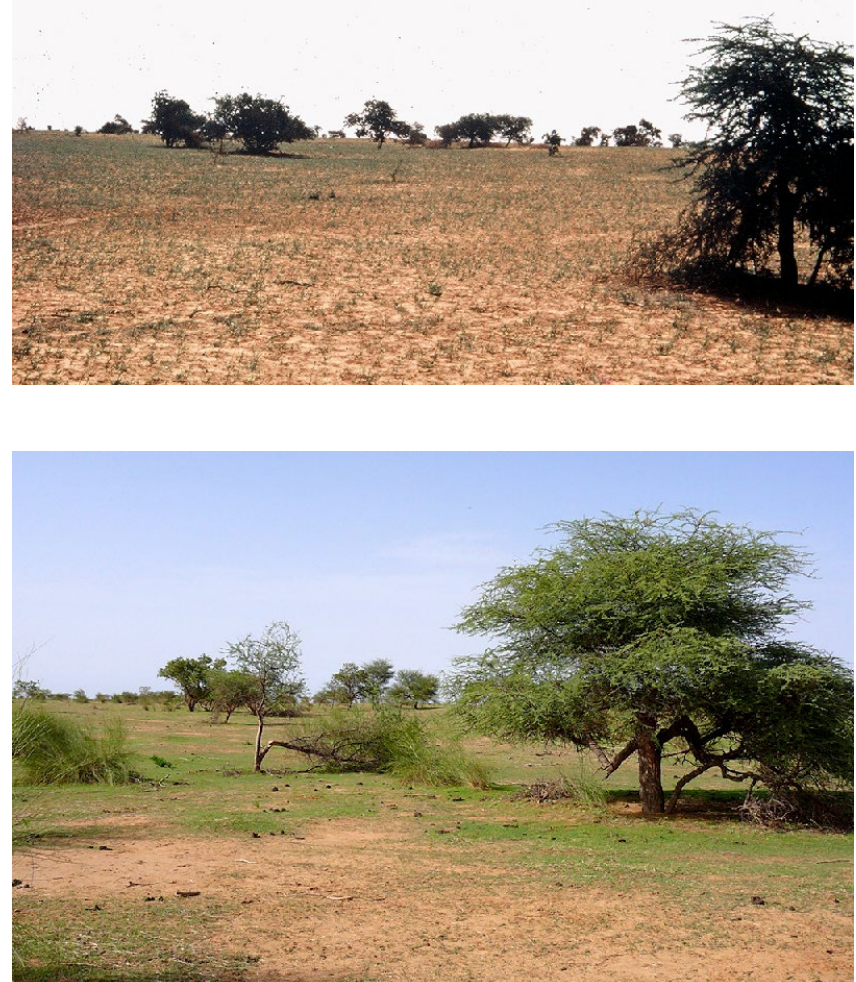
The impact of livestock on woody plant populations is indirect, either favoring woody plants in the competition with more intensely used grass species, or helping seed dispersion of species such as Balanites aegyptiaca and most Acacia. On the opposite, repeated browsing and trampling of seedlings may slow the recruitment or preferred species. However, high grazing pressure around water ponds and pastoral camps has not impeded woody plant recruitment after the 1980s' drought (Hiernaux et al., 2009). Remote sensing confirms that the woody plant cover has been globally increasing since the 1980s in pastoral lands (Brandt et al., 2016) and is most often higher close to livestock concentration sites, with fewer bushes and more large trees (Rasmussen et al., 2018).

\section{Impact of grazing livestock at ecosystem scale}

At the ecosystem scale, grazing livestock accelerates the recycling of vegetation organic matter, its decomposition and mineralization (Manlay et al., 2004). It thus stimulates soil biological activity and activates nutrient cycling by excretion deposit and litter burying. Incidentally, this process reduces the risk of fires and thus the loss of carbon and nitrogen due to fires. The concentration of feces and urine deposit during resting/rumination generates a spatial transfer of organic matter and nutrients from wide grazing areas to the smaller areas of camps and corrals, and next to water ponds (Landais and Lhoste, 1993). In agropastoral ecosystems, this transfer is the major way to increase the soil fertility of selected crop fields. This is achieved by corralling livestock at night in the field during the dry season and in the neighboring fallow during the wet season, or by collecting manure in paddocks and carrying it to the field by cart (Schlecht et al., 2004). In creating these hot spots of soil fertility, the grazing livestock plays a major role in crop diversification and intensification (Hiernaux and Diawara, 2014).

The environmental cost of the recycling function could be the contribution of ruminants to greenhouse gas emission, e.g. enteric $\mathrm{CH} 4$, or $\mathrm{CO} 2, \mathrm{~N} 2 \mathrm{O}$ and $\mathrm{CH} 4$ during the decomposition of deposited excreta on the soil or surface water. First assessments of these contributions raised concerns about the responsibility of pastoral breeding in climate change processes. Concerns intensified as the estimated emissions were reported relative to animal production, which is quite low (Gerber et al., 2013) and calculated based on generous (+ 40\%) estimates of the forage intake (Assouma et al., 2018). Recent works conducted in a pastoral breeding system in Northern Senegal downsized these emissions and concluded that the carbon cycle of pastoral breeding was seasonally contrasted but annually neutral (Assouma et al., 2017b; 2019a; 2019b).

\section{- COMPARING THE CHALLENGES OF CLIMATE AND SOCIETAL CHANGES}

Regardless of the increase in atmosphere temperature and $\mathrm{CO}_{2}$ concentration, and of the direction of rainfall changes, the climate in sub-Saharan West and Central Africa should remain monsoonal with a summer rainy season of decreasing duration with latitude, regularly alternating with a fall to spring dry season of increasing duration with latitude. Rainfall should continue to be provided by convective storms moving from east to west and thus remain patchy and variable within the season. Thus, the quality of the forage offer should remain highly seasonal and patchily distributed. Besides, the severe livestock losses caused by the two main droughts (Toulmin, 1987) have been mostly compensated (Corniaux et al., 2012) although the average size of herds decreased (Colin de Verdière, 1994). This livestock population reconstitution was, however, less effective in the harshest Northern Sahelian areas and brought about changes in species and herd breed composition with a relative increase in small ruminants to the detriment of cattle (Turner, 1999), and a progression of camels to the South (Bourn and Wint, 1994; Anderson and Monimart, 2009). Both trends have been interpreted as adaptations to either more arid climates or the reduction in grazing resources and access to these resources (Serpantié et al., 1988). They may also respond to changes in the market demand (Wane et al., 2009), skilled labor availability or other social traits within pastoralist families (Turner, 1999). For example, the intensified market demand for sheep sacrificed during Muslim religious celebrations, particularly in wealthier urban areas, has stimulated the relative increase in sheep breeding during the last decades in Senegal (Wane et al., 2009). In the short term, social and institutional changes appear to shape pastoral breeding more than climate change does. The historical shrinkage of rangeland space, and area fragmentation and access restriction, while pastoralist families and livestock are growing, is pushing pastoral breeding to limits of animal production viability (Lesnoff et al., 2012). The benefit of herd mobility and mixed species and breed complementarity in selecting the best fodder resources offered by Sahel immensity during time of abundance (wet and early dry seasons) only holds if the gains made can be supported by limited losses during the dry season. This is particularly true for livestock reproduction performances based on female condition over longer periods than just one season. Fertility rates of adult females are already low, which strongly affects pastoral breeding productivity (Wilson, 1986). The quality of optimizing livestock grazing selection by organizing daily grazing circuits and season transhumance is acknowledged in pastoral breeding (Ayantunde et al., 1999). Communal management appears more efficient and less costly to adapt to the variable and patchy fodder resources. Yet, pastoralists' reduced access to water and grazing resources, especially during the dry season in the agropastoral subhumid zone, questions the sustainability of pastoral breeding. Alternative production systems have been suggested to overcome the constraints faced by pastoral breeding.

\section{- ALTERNATIVES TO PASTORAL BREEDING: HOW THEY FACE GLOBAL CHANGES}

\section{Ranching}

One alternative to pastoral breeding is ranching, which is also reproduction oriented and livestock fed mostly by grazing-browsing, but rangelands are privately managed instead of being pastoral commons. It requires fencing, which involves costly initial investments from external funding, then high maintenance and social costs that are difficult to meet on the long term. It implies a reduction in herd mobility even when sophisticated paddock rotation is planned (Savory, 1983). With its private access and use of fences, ranching impedes seasonal herd mobility at regional scale. Control of the stocking rate often sustains ranching but the lack of flexibility leads to the under-use of resources in some places with enhanced risks of bush encroachment or fire, and overuse in other places with the risk of favoring invasive refusals. These risks are reinforced by breeding a single species, often a single breed, as observed in most ranches, thus losing the benefits of complementary feeding behaviors in multispecies breeding. Socially, the high investment needed to set up and manage a ranch excludes local pastoral families and isolates the often distant owner from the manager and waged herders. This can cause rapid erosion of herders' labor skills as they lose full responsibility. Attempts to develop ranching from the colonial time have generally failed in the region (Boutrais, 1990) with a few exceptions relying on institutional and environmental peculiarities (Achard and Chanono, 2006). An interesting trial to introduce a scientifically controlled ranching, funded by German Cooperation, was conducted in the Ferlo in Senegal starting in 1981. It failed both technically and economically in spite of free investments for the few selected pastoralists who benefited from 
the project (Thébaud et al., 1995). If ranching were to be developed, supported by policies of tenure privatization and investments in livestock production by the wealthy, national or foreigners, it would raise yet other obstacles to the remaining pastoral breeders. In addition, the ecosystem benefit of transhumance, especially the transfer of soil fertility in the visited agropastoral ecosystems, would be lost as well as the provision of cheap young animals to sedentary specialized livestock production units.

\section{Stall feeding}

Another alternative to pastoral breeding is to reduce seasonal and regional mobility, at least during the dry season, by feeding livestock substantial quantities of either collected and conserved forages such as hay, haulms, cereal stubble, or even agro-industrial by-products. This trend is already present in pastoral breeding system facing severe cuts in dry-season access to rangelands (Fernandez-Rivera et al., 2005). As a result, seasonal and regional herd mobility has been reduced or suppressed, achieving to decouple stocking rates and forage availabilities with the risk of overgrazing during the growing season, leading to reduced forage resources all year round. In addition, pastoral breeders are not best placed to produce or import livestock fodder or agro-industrial by-products, as they are generally in remote, badly connected areas, and landlocked. The high cost of production, storage and transportation requires investments that only wealthy people or external funding can support. As with ranching, the benefits of dry season transhumance for soil fertility and provision of cheap young animals to the markets will be lost.

\section{Ranching and stall feeding}

The two alternatives could be combined with ranching in pastoral areas supported by stall feeding in the dry season. Actually, it would be the only option to maintaining ranching in the long run as shown by the management of the few successful ranch exceptions (Achard and Chanono, 2006). The high cost of each alternative management cumulates reinforcing the dependence on external funding and related social costs. The risks of wet-season overgrazing degradation are reinforced by the external sources of dry-season feeding.

\section{PERSPECTIVES: NEW DEAL TO ADAPT PASTORAL BREEDING TO GLOBAL CHANGES}

By comparison with the two alternative strategies alone or combined, pastoral breeding with rangelands managed as commons and with seasonal mobility at regional scale appears the most adapted option to cope with the seasonality and interannual variability of forage availability and quality, both likely to become even more variable and patchy with climate change. Pastoral practices can be improved by offering flexible optimization of livestock grazing and by decentralizing the organization of daily grazing circuits and seasonal transhumance (Chirat et al., 2014). Communal management also appears as a more efficient and less costly solution to adapt to the variable patchiness of resources (Krummel and Dritschilo, 1977; Cossins, 1985). It ensures the most reactive livestock mobility, key to control the risks of degradation by overgrazing during the wet season and promote ecosystem resilience in the face of monsoonal climate vagaries (Breman and de Wit, 1983). Moreover, pastoral breeding has a long history of connection with specialized livestock production systems in subhumid and periurban areas, providing young animals through direct contracts as well as livestock markets (Touré et al., 2012). This provision includes young males either for drafting (Vall et al., 2003) or fattening, and young females to renew dairy herds in periurban units. The dry season transhumance in subhumid and wetland agropastoral areas also benefits cropland soil fertility management by accelerating the organic matter recycling and transferring fertility to selected manured fields (Landais and Lhoste, 1993; Hiernaux and Diawara, 2014).

Yet maintaining or reviving pastoral breeding in West and Central Africa would require a proactive policy addressing the main constraints faced by pastoral breeders. Civil insecurity, terrorism and banditry in several pastoral regions not limited to the Sahara deserve urgent national and international investment (Bonnet, 2013). However, on the longer term, only large infrastructure investments in education, health, roads and communication will ensure security, and help pastoral breeding to adapt to societal changes. More specific policies are also necessary to ensure the future of pastoral breeding, starting by the recognition of its access to water and forage resources (Lavigne-Delville and Chauveau, 1998; Bonnet and Hérault, 2011), the empowerment and capacity building of professional organizations and herders' associations. First steps in the political recognition of the economic and social contribution of pastoral breeding were initiated as recommendations in a series of conferences (Déclaration de D'Njaména, 2013), and political agreements (Déclaration de Nouackchott, 2013). This renewed interest revived the funding of dedicated development projects such as the Regional Pastoralism Support Project in the Sahel (PRAPS), Regional Investment Program for Livestock Development in Coastal Countries (PRIDEC), Livestock Development Support Project (PADEL) (de Haan et al., 2016). In pastoral regions, the objective is to complete, rehabilitate and manage hydraulic and veterinary infrastructures in consultation with the pastoral breeders' associations and territorial authorities (Bonnet et al., 2005). In agropastoral regions, the objective is to set frameworks for local and regional consultation and contractual agreements between pastoralists, agropastoralists and crop farmers on the organization and by building the needed infrastructures (water points, livestock pathways, grazing areas, corralling sites, shelters...) to make dry season transhumance more efficient and mutually beneficial (Oxby, 1985).

\section{Acknowledgments}

The illustrations come from field work in Mali and Niger funded by ILRI (International Livestock Research Institute, Nairobi, Kenya). More recent data collection was funded by AMMA-CATCH Observatory (www.amma-catch.org). The results on the carbon balance of pastoral livestock in Senegal were obtained by SELMET (Tropical and Mediterranean Animal Production Systems) research unit of CIRAD (French Agricultural Research Centre for International Development) and PPZS (Project Pastoralism in Arid Lands, Dakar, Senegal).

\section{Author contributions statement}

$\mathrm{PH}$ and MHA wrote the article.

\section{Conflicts of interest}

The study was conducted without any conflict of interest.

\section{REFERENCES}

Abbadie L., 1984. Evolution saisonnière du stock d'azote dans la strate herbacée d'une savane soumise aux feux en Côte d'Ivoire. Acta Oecologica, Oecologia Plantarum, 5 (19): 321-334

Achard F., Chanono M., 2006. Exemple d'une gestion pastorale réussie au Sahel : la station d'élevage de Toukounous (Niger). Sécheresse, 17 (1-2): 76-82

Ag Mahmoud M., 1992. Le Haut Gourma central (Ve région de la République du Mali). Présentation générale. CEFE/CNRS ,Montpellier, France, $2^{\mathrm{e}}$ édition révisée, $133 \mathrm{p}$.

Anderson S., Monimart M., 2009, IIED, Recherche sur les stratégies d'adaptation des groupes pasteurs de la région de Diffa, Niger oriental, $102 \mathrm{p}$. 
Anyamba A., Tucker C. J., 2005. Analysis of Sahelian vegetation dynamics using NOAA-AVHRR NDVI data from 1981-2003. J. of Arid Envir., 63 (3), 596-614

Assouma M. H., Lecomte P., Corniaux C., Hiernaux P., Ickowicz A., Vayssières J., 2019a. Pastoral landscapes in the Sahel: a carbon balance with unexpected potential for climate change mitigation. Montpellier, CIRAD, Perspective 52, doi: 10.19182/agritrop/00083

Assouma, M.H., Hiernaux, P., Lecomte, P., Ickowicz, A., Bernoux, M., Vayssières, J., 2019b. Contrasted seasonal balances in a Sahelian pastoral ecosystem result in a neutral annual carbon balance. J. Arid Envir., 162: 62-73, doi: 10.1016/j.jaridenv.2018.11.013

Assouma M.H., Lecomte P., Hiernaux P., Ickowicz A., Corniaux C., Decruyenaere V., Diarra A.R., et al., 2018. How to better account for livestock diversity and fodder seasonality in assessing the fodder intake of livestock grazing semi-arid sub-Saharan Africa rangelands. Livest. Sc., 216: 16-23, doi : 10.1016/j.livsci.2018.07.002

Assouma M.H., Mottet A., Lecomte P., Velascogil G., Hiernaux P., Vayssières J., 2017a. Browsed trees and shrubs fodder by pastoral herds efficiency in the sahelian rangeland. In: Proc. Int.. Conf. on Pastoralism in curren global changes, Dakar, 20-24 Nov. 2017, PPZS, Dakar, Senegal, 235-236

Assouma M.H., Serça D. Guérin F., Blanfort V., Lecomte P., Touré I., Ickowicz A., et al., 2017b. Livestock induces strong spatial heterogeneity of soil $\mathrm{CO} 2, \mathrm{~N} 2 \mathrm{O}, \mathrm{CH} 4$ emissions within a semi-arid sylvo-pastoral landscape in West Africa. J. of Arid Land, 9: 210-221, doi: 10.1007/s40333-017-0001-y

Aubréville A., 1949. Climats, Forêts et Désertification de I'Afrique Tropicale Société d'Editions Géographiques, Maritimes et Coloniales, Paris, France, $351 \mathrm{p}$.

Ayantunde A.A., Hiernaux P., Fernandez-Rivera S., van Keulen H., Udo H.M.J., 1999. Selective grazing by cattle on spatially and seasonally heterogeneous rangelands in the Sahel. J. Arid Envir., 42: 261-279, doi : 10.1006/jare.1999.0518

Ayantunde A.A., Hiernaux P., Fernandez-Rivera S., Sangare M., 2018. Nutrient management in livestock systems in West Africa Sahel with emphasis on feed and grazing management. In: Improving the profitability, sustainability and efficiency of nutrients through site specific fertilizer recommendations in West Africa agro-ecosystems. (Eds. Bationo, A., Ngaradoum, D. Youl, S., Lompo, F. and Fening, J.). Springer Intern. Publ., Cham, Suisse : 11-23, doi 10.1007/978-3-319-58789-9_2

Bassett T.J., 1988. The Political Ecology of Peasant-Herder Conflicts in the Northern Ivory Coast. Ass. Am. Geog. Annals, 78 (3): 453-472, doi: 10.1111/j.1467-8306.1988.tb00218.x

Bationo A., Mokwunye A.U., 1991. Role of manures and crop residue in alleviating soil fertility constraints to crop production: With special reference to the Sahelian and Sudanian zones of West Africa. Fertilizer Res., 29: 117-125, doi: 10.1007/BF01048993

Bichet A., Diedhiou A., 2018. West African Sahel has become wetter during the last 30 years, but dry spells are shorter and more frequent. Climate Res. 75 (2): 155-162, doi :10.3354/cr01515

Bonfiglioli A.M, 1988. Dudal. Histoire de famille et histoire de troupeau chez un groupe de Wodaabé du Niger. Ed. Maison des Sc. De I'Homme/ Cambridge Univ. Press. Paris, France, Cambridge, UK, 293p.

Bonnet B., 2013. Vulnérabilité pastorale et politiques publiques de sécurisation de la mobilité pastorale au Sahel. Mondes dév., 164: 71-91, doi: 10.3917/med.164.0071

Bonnet B., Hérault D., 2011. Gouvernance du foncier pastoral et changement climatique au Sahel. Land Tenure J., 2: 157-187

Bonnet B., Marty A., Demante M.J., 2005. Hydraulique et sécurisation des systèmes pastoraux au Sahel. Appui à la gestion locale. Démarches et méthodes, IRAM, Paris, France, 28 p.

Boudet G., 1972. Désertification de I'Afrique tropicale sèche. Adansonia, sér. 2, 12 (4): 505-524

Bourn D., Wint W., 1994. Livestock, land-use and agricultural intensification in sub-saharan Africa. Pastoral Development Network Paper 37a, ODI London, UK, 24 p.

Boutrais J., 1990. Derrière les clôtures... Essai d'histoire compare de ranchs africains. ORSTOM Cah. SC. Hum., 26 (1-2): 73-95

Brabant P., 2010. A land degradation assessment and mapping method. A standard guideline proposal. Les dossiers thématiques du CSFD 8, Agropolis International, Montpellier, France, $52 \mathrm{p}$.
Brandt M., Hiernaux P., Rasmussen K., Mbow C., Kergoat L., Tagesson T., Ibrahim Y. Z., et al., 2016. Assessing woody vegetation trends in Sahelian drylands using MODIS based seasonal metrics. Rem. Sens. Envir., 183: 215-225, doi: 10.1016/j.rse.2016.05.027

Brandt M., Rasmussen K., Hiernaux P., Herrmann S., Tucker C.J., Tong X, Tian F., et al., 2018. Reduction of tree cover in West African woodlands and promotion in semi-arid farmlands. Nat. Geosc.. doi: 10.1038/s41561-0180092-x

Brandt M., Verger A., Diouf A.A., Baret F., Samimi C., 2014. Local vegetation trends in the Sahel of Mali and Senegal using long time series FAPAR satellite products and field measurements (1982-2010). Rem. Sens., 6: 24082434, doi: 10.3390/rs6032408

Breman H., de Wit C.T., 1983. Rangelands productivity and exploitation in the Sahel. Science, 221 (4618):1341-1347, doi: 10.1126/science.221.4618.1341

Breman H., Groot J.J.R., van Keulen H., 2001. Resource limitations in Sahelian agriculture. Gl. Envir. Change, 11: 59-68, doi: 10.1016/S09593780(00)00045-5

Brooks N., Di Lernia S., Drake N. Chiapello I., Legrand M., Moulin C., Prospero J., 2005. The environment-society nexus in the Sahara from prehistoric times to the present day. J. North Afr. Stud., 304, 253-292, doi: 10.1080/13629380500336680

Casenave A.,Valentin, C., 1992. A runoff capability classification system based on surface features criteria in the arid and semi-arid areas of West Africa. J. Hydrol., 130: 231-249, doi: 10.1016/0022-1694(92)90112-9

César J., 1981. Cycles of the biomass and regrowths after cutting in savanna (Ivory Coast). Rev. Elev. Méd. Vét. Pays Trop., 34 (1): 73-81, doi : 10.19182/remvt.8286

César J., Zoumana C., 1993. Conséquence de I'accroissement démographique sur la qualité de la jachère dans le nord de la Côte d'Ivoire. In: La jachère en Afrique de I'Ouest. (Eds. Floret C., Serpantié G.), Orstom, Paris, France 415-434

Chirat G., Groot J.C.J., Messad S., Bocquier F., Ickowicz A., 2014. Instantaneous intake rate of free-grazing cattle as affected by herbage characteristics in heterogeneous tropical agro-pastoral landscapes. Appl. Anim. Behav. Sci., 157: 48-60, doi: 10.1016/j.applanim.2014.06.003

Cissé M.I., Breman H., 1975. Influence of the intensity of exploitation on the productivity of grasslands. In Evaluation and mapping of tropical African rangelands. ILCA, Addis Ababa, Ethiopia, 207-212

Colin de Verdière P., 1994. Investigation sur l'élevage pastoral. Rapport final du projet STD2. Hohenheim Univ., Stuttgart, Germany/ Cirad-EMVT, Maisons-Alfort, France, 249 p.

Corniaux C., Lesnoff M., Ickowicz A., Hiernaux P. Diawara M.O., Sounon A., Aguilhon M., et al., 2012. Contribution de l'élevage à la réduction de la vulnérabilité des ruraux et à leur adaptabilité aux changements climatiques et sociétaux en Afrique de l'Ouest au sud du Sahara. ECLIS, livrable 3.1, GET, Toulouse, 43 p.

Cossins N.J., 1985. The productivity and potential of pastoral systems. ILCA Bull. , Addis Ababa, Ethiopia, 21: 10-15

Dardel C., Kergoat L., Mougin E., Hiernaux P., Grippa M., Tucker C. J., 2014. Re-greening Sahel: 30 years of remote sensing data and field observations (Mali, Niger). Remote Sens. Envir., 140: 350-364, doi: 10.1016/j. rse.2013.09.011

De Haan C., Dubern E., Garancher B., Quintero.C., 2016.Pastoralism Development in the Sahel: A Road to Stability? World Bank, Washington DC, USA, $43 \mathrm{p}$

Déclaration de N’Djamena, 2013. Elevage pastoral. Une contribution durable au développement et à la sécurité des espaces saharo-sahéliens. Coll. Régional 27-29 Mai 2013, N’Djaména, Tchad, 7 p.http://www.hubrural. org/IMG/pdf/declaration_de_n_djamena_29_mai_2013.pdf

Déclaration de Nouakchott, 2013. Mobilisons ensemble un effort ambitieux pour un pastoralisme sans frontières, 29 Oct. 2013, 4 p., www.oie.int/doc/ ged/D12969.pdf

Denis E., Moriconi-Ebrard F., 2009. La croissance urbaine en Afrique de I'Ouest : De l'explosion à la prolifération. La Chronique du CEPED, 1-5

Descroix L., Genthon P., Amogu O., Rajot J.L., Sighomnou D., Vauclin M., 2012. Change in Sahelian Rivers hydrograph: The case of recent red floods of the Niger River in the Niamey region. Glob. Planet. Chang., 98-99: 1830, doi: 10.1016/j.gloplacha.2012.07.009

Dodd J. L., 1994. Desertification and degradation in Sub-Saharan AfricaThe role of livestock. Bioscience, 44 (1): 28-34, doi : 10.2307/1312403 
Doutressoulle G., 1952. L'élevage au Soudan Français. Ed. Larose, Paris, France, 298 p.

Favreau G., 2002. Le déboisement : origine d'une hausse durable de la recharge et des nitrates en aquifère libre semi-aride (Sahel, Niger). Pangea, 37/38: 25-34

Fernandez-Rivera S., Hiernaux P., 1995. Effect of stocking rate and herd composition on goats and sheep output in Sahelian rangelands. Presented at the annual meeting of the American Society of Animal Sciences in Orlando, Florida, 25-28 July 95. J. Anim. Sc., 73 (1), 206

Fernandez-Rivera S., Hiernaux P., Williams T.O., Turner M.D., Schlecht E., Salla A., 2005. Nutritional constraints to grazing ruminants in the millet-cowpea-livestock farming system of the Sahel. In: Coping with feed scarcity in smallholder livestock systems in developing countries (Eds. A. A. Ayantunde A.A., Fernandez-Rivera S., McCrabb G.), ILRI, Nairobi, Kenya, 157-182

Fournier A., 1996. Dans quelle mesure la production nette de matière végétale herbacée dans les jachères en savane soudanienne est-elle utilisable pour le pâturage ? In La jachère, lieu de production, (Ed. Floret C.), CNRST, Bobo Dioulasso, Burkina Faso/Orstom: 101-111

Gallais J., 1975 - Pasteurs et paysans du Gourma. La condition sahélienne. Mémoire CEGET, CNRS, Paris, France, 239 p.

Gal L., Grippa M., Hiernaux P., Pons L., Kergoat L., 2017. The paradoxical evolution of runoff in the pastoral Sahel. Analysis of the hydrological changes over the Agoufou watershed (Mali) using the KINEROS-2 model. Hydrol. Earth Syst. Sci., 21: 4591-4613, doi: 10.5194/hess-21-4591-2017

Gardelle J., Hiernaux P., Kergoat L., Grippa M., 2010. Less rain, more water in ponds: A remote sensing study of the dynamics of surface waters from 1950 to present in pastoral Sahel (Gourma region, Mali). Hydrol. Earth Syst. Sc., 14: 309-324, doi: 10.5194/hess-14-309-2010

Gerber P.J., Steinfeld H, Henderson B, 2013. Tackling Climate Change through Livestock-A Global Assessment of Emissions and Mitigation Opportunities. Food and Agriculture Organization of the United Nations, Roma, Italy, $139 \mathrm{p}$.

Ghannoum O., von Caemmerer S., Ziska L.H., Conroy J.P., 2000. The growth response of $\mathrm{C} 4$ plants to rising atmospheric $\mathrm{CO}_{2}$ partial pressure: a reassessment. Plant, Cell Envir., 23: 931-942, doi: 10.1046/j.13653040.2000.00609.x

Guengant J.P., May J.F., 2011. L'Afrique subsaharienne dans la démographie mondiale. Études, 415: 305-316

Guerin, H., 1994. Valeur alimentaire des fourrages ligneux consommés par les ruminants en Afrique centrale et de l'Ouest. Cirad-emvt, Maisons-Alfort, France, $451 \mathrm{p}$.

Guichard F., Kergoat L., Hourdin F., Léauthaud C., Barbier J., Mougin E., Diarra B., 2017. Le réchauffement climatique observé depuis 1950 au Sahel. In : Les sociétés rurales face aux changements climatiques et environnementaux en Afrique de l'Ouest ( Eds. Sultan B., Lalou R., Sanni M.A., Oumarou A., Soumaré M.A.), IRD éditions, Marseille, France, 23-42

Hanan N.P., Prevost Y., Diouf A., Diallo O., 1991. Assessment of desertification around deep wells in the Sahel using satellite imagery. J. Appl. Ecol., 28: $173-186$, doi: $10.2307 / 2404123$

Hiernaux P., 1984. Is it possible to improve the traditional grazing management in the flood plain of the Niger river in central Mali ? In: Rangelands: a resource under siege. (Ed. Joss P.J.) Proc. of the $2 \mathrm{~d}$ Int. Rangeland Cong., Aust. Acad. of Sc., Canberra, Australia, 201-204

Hiernaux P., Adamou K., Moumouni O., Turner M.D., Tong X., Savadogo P., Tong X., Mougin E.., Malam Issa O., 2019. Expanding networks of field hedges in densely populated landscapes in the Sahel. For. Ecol. Manag., 440: 178-188, doi: 10.1016/j.foreco.2019.03.016

Hiernaux P., Adamou K., Zezza A., Ayantunde A.A.,, Federighi G., 2016. Milk offtake of cows in smallholder farms of semiarid Sahel: low yields with high value! Rev. Elev. Med. Vet. Pays Trop., 69 (4): 143-153, doi: 10.19182/remvt.31199

Hiernaux P., Bielders C.L., Valentin C., Bationo A., Fernandez-Rivera S., 1999. Effects of livestock grazing on physical and chemical properties of sandy soil in sahelian rangelands. J. Arid Envir., 41: 231-245, doi:10.1006/ jare.1998.0475

Hiernaux P., Dardel C., Kergoat L., Mougin E., 2016. Desertification, adaptation and resilience in the Sahel : lessons from long-term monitoring of agro-ecosystems. In: The end of desertification? (Eds. Behnke R.H., Mortimore M.), Springer-Verlag Berlin Heidelberg, Germany, 147-178, doi: 10.1007/978-3-642-16014_6
Hiernaux,P., Diarra L., Trichon V.,Mougin E., Soumaguel N., Baup F., 2009. Woody plant population dynamics in response to climate changes from1984 to 2006 in Sahel (Gourma,Mali). J. Hydrol., 375: 103-113, doi: 10.1016/j.jhydrol.2009.01.043

Hiernaux P., Diawara M.O., 2014. Livestock: Recyclers that promote the sustainability of smallholder farms. Rural, 21(4): 9-11

Hiernaux P., Diawara M.O., Kergoat L., Mougin E., 2015. La contrainte fourragère des élevages pastoraux et agro-pastoraux du Sahel. Adaptations et perspectives. In : Les sociétés rurales face aux changements climatiques et environnementaux en Afrique de I'Ouest (Eds. Sultan B., Lalou R., Sanni M.A., Oumarou A., Soumaré M.A.). IRD éditions, Marseille, France, 171 192, doi : 10.4000/books.irdeditions.9631

Hiernaux P., Le Houérou H.N., 2006. Les parcours du Sahel. Sécheresse, $17(1-2): 51-71$

Hiernaux P., Mougin E., Soumaguel N., Diawara M, Auda Y, Le Dantec V. 2013. Do seasonal maximum growth rates explain the large variations in annual yields of the herbaceous in Sahel rangelands? Doc. Trav. ECLIS, GET, Toulouse, France, $27 \mathrm{p}$.

Hiernaux P., Turner M.D., 1996. The effect of clipping on growth and nutrient uptake of Sahelian annual rangelands. J. Appl. Ecol., 33: 387-399, doi: $10.2307 / 2404760$

Ickowicz A., Ancey V., Corniaux C., Duteurtre G., Poccard-Chappuis R., Touré I., Vall E., et al., 2012. Crop-livestock production systems in the Sahel: Increasing resilience for adaptation to climate change and preserving food security. In: Building resilience for adaptation to climate change in the agricultural sector.( Eds. Meybeck A., Lankoski J., Redfern S., Azzu N., Gitz V.), Proc. of FAO/OECD workshop 23-24 April 2012: 261-294

IPCC, 2013. Climate Change 2013: The Physical science basis. Summary for policymakers. IPCC 5th assessment report, $36 \mathrm{p}$.

Krätli S., 2005. Animal science and the representation of local breeds: looking into the sources of current zootechnical knowledge on the Bororo zebu. Conf. 'Veterinary Science, Disease, and Livestock Economies' St. Anthony's College, Oxford, UK

Krätli S., Schareika N., 2010. Living Off Uncertainty: The intelligent animal production of dryland pastoralists. Eur. J. Dev. Res., 22: 605-622, doi:10.1057/ejdr.2010.41

Kruska R.L., Reid R.S., Thornton P.K., Henninger N., Kristjanson P.M., 2003. Mapping livestock-oriented agricultural production systems for the developing world. Agric. Syst., 77: 39-63, doi: 10.1016/S0308$521 \times(02) 00085-9$

Krummel J., Dritschilo S., 1977. Resource cost of animal protein production. World Anim. Rev. 21(6)

Landais E., Lhoste P., 1993. Systèmes d'élevage et transferts de fertilité dans la zone des savanes africaines. II. Les systèmes de gestion de la fumure animale et leur insertion dans les relations entre l'élevage et l'agriculture. Cah. Agric., 2 : 9-25

Lavigne-Delville P., Chauveau J.P., 1998. Quels fondements pour des politiques foncières en Afrique francophone? In : Quelles politiques foncières pour l'Afrique rurale? Réconcilier pratiques, légitimité et légalité. Ed. Lavigne-Delville P., Karthala/Coopération française, Paris, France, 721-736

Leauthaud C., Kergoat L., Hiernaux P., Grippa M., Musila W., Duvail S., Albergel J., 2018. Modelling the growth of floodplain grasslands to explore the impact of changing hydrological conditions on vegetation productivity. Ecol. Model., 387: 220-237, doi: 10.1016/j.ecolmodel.2018.09.015

Lebel T., Ali A., 2009. Recent trends in the Central and Western Sahel rainfall regime (1990-2007). J. Hydrol., 375 (1-2): 52-64, doi : 10.1016/j.jhydrol.2008.11.030

Le Houérou H.N., 1989. The grazing land ecosystems of the African Sahel. Springer-Verlag, Cham, Switzerland, 281p., doi : 10.1007/978-3-64274457-0

Lesnoff M., Corniaux C., Hiernaux P., 2012. Sensitivity analysis of the recovery dynamics of a cattle population following drought in the Sahel region. Ecol. Model., 232 : 28-39, doi : 10.1016/j.ecolmodel.2012.02.018

Lhoste P., Dollé V., Rousseau J., Soltner D., 1993. Manuel de zootechnie des régions chaudes. Les systèmes d'élevage, coll. Précis d'Élevage, Min. de la Coop., Paris, France, 288 p.

Maman Moutari E., Giraut, F., 2013. Le corridor de transhumance au Sahel : un archétype de territoire multisitué Espace Géog., 42 (4): 306-323 doi:10.3917/eg.424.0306 
Manlay R.J., Ickowicz A., Masse D., Feller C., Richard D., 2004. Spatial carbon, nitrogen and phosphorus budget of a village of the West African savanna-II. Element flows and functioning of a mixed farming system. Agric. Syst., 79: 83-107, doi: 10.1016/S0308-521X(03)00054-4

Manoli C.V., Ancey C., Corniaux A., Ickowicz B., Moulin C.H., 2014. How Do Pastoral Families Combine Livestock Herds with Other Livelihood Security Means to Survive? The Case of the Ferlo Area in Senegal. Pastor. Res., Policy Pract., 4 (3): 11 p., doi: 10.1186/2041-7136-4-3

Miehe S., Kluge J., Von Wehrden H., 2010. Long-term degradation of Sahelian rangeland detected by 27 years of field study in Senegal. J. Appl. Ecol., 47(3): 692-700, doi: 10.1111/j.1365-2664.2010.01815.x

Mougin E., Lo Seen D. , S. Rambal, Gaston A., Hiernaux P., 1995. A regional Sahelian grassland model to be coupled with multispectral satellite data. 1: validation. Remote Sens. Environ., 52 (3): 181-193, doi: 10.1016/00344257(94)00126-8

Nicholson S.E., 2013. The West African Sahel: A review of recent studies on the rainfall regime and its interannual variability. ISRN Met., $32 \mathrm{p}_{\prime \prime}$ doi: $10.1155 / 2013 / 453521$

Oxby C., 1985. Settlement schemes for herders in the subhumid tropics of West Africa: issues of land rights and ethnicity. Pastoral Development Network, ODI, London, UK, 19f, 16 p.

Ozer P., Laminou Manzo O., Tidjani A.D., Djaby B., de Longueville F., 2017 Evolution récente des extrêmes pluviométriques au Niger (1950-2014) Geo-Eco-Trop 41 (3): 375-384

Panthou G., Vischel T., Lebel T., 2014. Recent trends in the regime of extreme rainfall in the Central Sahel. Intern. J. Clim., 34 (15): 3998-4006, doi: 10.1002/joc.3984

Penning de Vries F.W.T., Djiteye M.A. (Eds.), 1982. La productivité des pâturages sahéliens, une étude des sols, des végétations et de l'exploitation de cette ressource naturelle. Pudoc, Wageningen, The Netherlands, $525 \mathrm{p}$.

Poorter H., Navas M.L., 2003. Plant growth and competition at elevated $\mathrm{CO}_{2}$ : On winners, losers and functional groups. New Phytol. 157: 175198, doi: 10.1046/j.1469-8137.2003.00680.x

Powell M.J., Pearson R.A, Hiernaux P., 2004. Crop-livestock interactions in the West African drylands. Agron.J., 96: 469-483, doi: 10.2134/ agronj2004.4690

Rasmussen K., Brandt M., Tong X., Hiernaux P., Diouf A.A., Assouma M.H., Tucker C.J., et al, 2018. Does grazing cause land degradation? Evidence from the sandy Ferlo in northern Senegal. Accepted in Land Degr. Dev., 29 (12): 4337-4347, doi: 10.1002/ldr.3170

Raynaut C., 2001. Societies and nature in the Sahel: Ecological diversity and social dynamics. Gl. Envir. Change, 11 : 9-18, doi: 10.1016/S09593780(00)00041-8

Sanogo O. M., 2011. Le lait, de l'or blanc ? Amélioration de la productivité des exploitations mixtes cultures-élevage à travers une meilleure gestion et alimentation des vaches laitières dans la zone de Koutiala, Mali. Thèse Doct., Université de Wageningen,, The Netherlands, 158 p.

Savory A. 1983. The Savory grazing method or holistic resource management. Rangelands 5 (4): 155-159.

Schlecht E., Hiernaux P., Achard F., Turner M.D., 2004. Livestock related nutrient budgets within village territories in western Niger. Nutrient Cycl. Agroecos., 68: 199-211, doi: 10.1023/B:FRES.0000019453.19364.70

Schlecht E., Hiernaux P., Kadaouré I., Hülsebusch C., Mahler F., 2006. A spatio-temporal analysis of forage availability and grazing and excretion behaviour of herded and free grazing cattle, sheep and goats in Western Niger. Agric., Ecos. Envir., 113: 226-242, doi: 10.1016/j.agee.2005.09.008
Serpantié G., Mersadier G., Tezenas du Montcel L., Mersadier Y., 1988. Transformation d'un système agro-pastoral soudano-sahélien. Cah. Rech. Dév., 20: 29-42

Sinclair A.R.E., Fryxell J.M., 1985. The Sahel of Africa: ecology of a disaster. Can. J. Zool., 63: 987-994, doi: 10.1139/z85-147

Steinfeld H., Gerber P., Wassenaar T., Castel V., Rosales M. de Haan C., 2006. Livestock's long shadow: environmental issues and options. FAO, Roma, Italy, 390 p.

Thébaud B., Batterbury S., 2001. Sahel pastoralists: opportunism, struggle, conflict and negotiation. A case study from eastern Niger. Gl. Envir. Changes, 11: 69-78, doi: 10.1016/S0959-3780(00)00046-7

Thébaud B., Grell H., Miehe S., 1995. Recognizing the effectiveness of traditional pastoral practices: lessons from a controlled grazing experiment in Northern Senegal. Drylands Issues Paper, 55, IIED, London, UK

Toulmin, C. 1987. Drought and the Farming Sector: Loss of animals and postdrought rehabilitation. Dev. Policy Rev., 5 (2): 125-148, doi: 10.1111/ j.1467-7679.1987.tb00370.x

Touré I., Ickowicz A., Wane A., Garba, I., Gerber P. (2012). Atlas of trends in pastoral systems in Sahel. CIRAD, Montpellier, France/ FAO, Roma, Italy, $36 \mathrm{p}$.

Turner M. D. 1999. Merging local and regional analysis of land-use change; the case of livestock in the Sahel. An. Ass. Am. Geog., 89 (2): 191-219, doi: 10.1111/1467-8306.00142

Turner M.D., Hiernaux P., 2008. Changing access to labor, pastures, and knowledge: The extensi-fication of grazing management in Sudano-Sahelian West Africa. Hum. Ecol., 36: 59-80, doi: 10.1007/s10745-007-9149-y

Turner, M.D., McPeak, J.G., Ayantunde, A. A. 2014. The role of livestock mobility in the livelihood strategies of rural peoples in semi-arid west Africa. Hum. Ecol., 42, doi: 10.1007/s10745-013-9636-2

Turner M.D., McPeak J. G., Gillin K., Kitchell E., Kimambo N., 2016. Reconciling flexibility and tenure security for pastoral resources: the geography of transhumance networks in eastern Senegal. Hum. Ecol. 44 (2): 199-215, doi: 10.1007/s10745-016-9812-2

United Nations, 2018. World Urbanization Prospects: The 2018 Revision. Department of Economic and Social Affairs, Population Division.

Vall E., Lhoste P., Abakar O., Dongmo Ngoutsop A.L., 2003. La traction animale dans le context en mutation de l'Afrique subsaharienne : enjeux de développement et de recherche. Cah. Agric., 12 (4) : 219-226

Valenza J. 1984. Surveillance continue des pâturages naturels sahéliens sénégalais. Résultats de 10 années d'observation. ISRA-LNERV, Dakar, Sénégal, Etude Agrostologique, 44, $53 \mathrm{p}$.

Wane A., Touré I., Ancey V. (2009). Pastoralisme et Recours aux marchés Cas du Sahel sénégalais (Ferlo). Cah. Agric., 19 (1): 14-20, doi: 10.1684/ agr.2009.0329

Wilson R.T., 1986. Livestock production in central Mali: long-term studies on cattle and small ruminants in the agropastoral system. ILCA Res. Rep.14, Addis Ababa, Ethiopia, 111 p.

World Bank, 2015. Project Paper for The Regional Sahel Pastoralism Support Project. CILSS/PRAPS, Ouagadougou, Burkina Faso.

Zdf, 2008. Une contribution à la compréhension de l'élevage mobile dans les régions de Zinder et de Diffa, Niger. Petit atlas analytique et synthétique. ZFD, DED, FNEN-DADDO, Code Rural, Niamey, Niger, 59 p.

Zoundi J. S., Hitimana L., 2008. Elevage et marché régional au Sahel et en Afrique de l'Ouest. Potentialité et défis. Club du Sahel et de l'Afrique de I'Ouest/OCDE, Paris, France, 162 p. 


\section{Résumé}

Hiernaux P., Assouma M.H. Adapter les élevages pastoraux d'Afrique tropicale de l'Ouest et du Centre aux changements globaux : synthèse de perspectives écologiques

L'élevage pastoral se définit comme un système d'élevage familial axé sur la reproduction et basé sur la pâture avec une gestion communautaire des ressources. Les élevages pastoraux diffèrent entre eux par la diversité des espèces et des races animales élevées, la taille et la conduite des troupeaux et I'ampleur de leur mobilité régionale. Le poids social, économique et environnemental des élevages pastoraux en Afrique subsaharienne occidentale et centrale est rappelé, de même que l'imputation qui leur est faite de dégradations environnementales. Les changements globaux auxquels l'élevage pastoral est confronté sont classés par domaine, climatique et sociétal, et par échelle de temps court ou long. Les impacts incriminés du bétail sur les écosystèmes sont évalués à court et à long terme. Les fonctions de l'élevage pastoral déjà affectées par les changements globaux, climatiques et sociétaux sont analysées. La capacité de deux systèmes alternatifs d'élevage, le ranching et la stabulation, à répondre à ces contraintes est examinée. Enfin, la capacité de s'adapter au mieux aux changements climatiques sur le long terme et aux changements sociétaux à court et à long terme est reconnue aux élevages pastoraux à condition que des investissements nationaux et internationaux soient consentis. La sécurité civile doit être restaurée et l'accès des pasteurs aux ressources en eau et en fourrage doit être sécurisé. Les organisations professionnelles et les associations devraient être habilitées à négocier des droits de pacage, et leurs compétences devraient être renforcées. II faut compléter, réhabiliter et gérer les infrastructures hydrauliques et vétérinaires, mais aussi investir largement dans des infrastructures adaptées en matière de santé, d'éducation et de communication dans les zones pastorales longtemps délaissées.

Mots-clés : pastoralisme, adaptation, changement climatique, changement social, écologie, Afrique au sud du Sahara

\section{Resumen}

Hiernaux P., Assouma M.H. Adaptación de la cría pastoral a los cambios globales en África tropical occidental y central: síntesis de las perspectivas ecológicas

Ganado pastoral se define como un sistema de ganadería familiar orientado a la reproducción, basado en el pastoreo, con recursos administrados por la comunidad. Los criadores pastorales se diferencian entre sí por la variedad de las especies y razas criadas, el tamaño y la gestión de los hatos y la escala de su movilidad regional. El peso social, económico y ambiental de la ganadería pastoral en Africa subsahariana occidental y central es paralelo a su responsabilidad en la degradación ambiental. Los cambios globales que enfrenta la ganadería pastoral se clasifican por dominios, climáticos y sociales, y por escalas de tiempo, cortas o largas. Los impactos incriminados a la ganadería sobre los ecosistemas se evalúan a corto y largo plazo. Se analizan las funciones de la cría pastoral ya afectadas por los cambios globales, ya sean climáticos o sociales. Se examina la capacidad de dos sistemas alternativos de cría de ganado, el ranching y la alimentación en establos, para responder a estas limitaciones. Por último, se observa que la cría pastoral es capaz de adaptarse mejor al cambio climático a largo plazo y a los cambios sociales a corto y largo plazo, siempre y cuando se realicen inversiones nacionales e internacionales. Debe restablecerse la seguridad civil y resguardar el acceso de los criadores al agua y los recursos forrajeros. Las organizaciones profesionales y las asociaciones deberían estar habilitadas para negociar los derechos de pastoreo y deberían mejorarse sus habilidades. Es necesario completar, rehabilitar y gestionar las infraestructuras hidráulicas y veterinarias, pero también invertir de forma significativa en infraestructuras adaptadas de salud, educación y comunicación en áreas pastorales extensamente abandonadas.

Palabras clave: pastoralismo, adaptación, cambio climático, cambio social, ecología, Africa al sur del Sahara 
